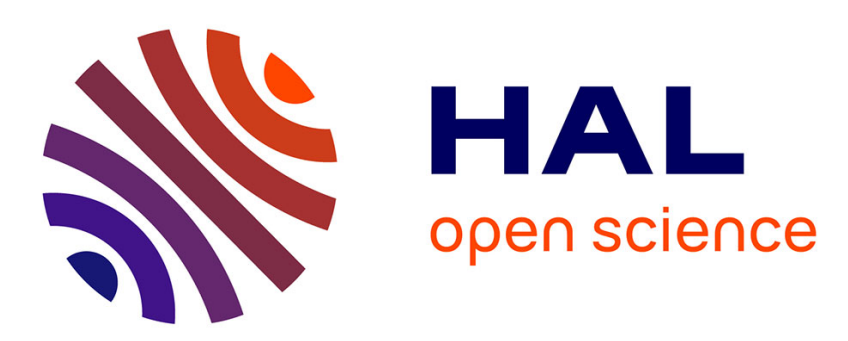

\title{
Modeling climate impact on an emerging disease, the Phytophthora alni-induced alder decline
}

\author{
Jaime Aguayo-Silva, Fabrice Elegbede, Claude Husson, Francois-Xavier
}

Saintonge, Benoit Marçais

\section{- To cite this version:}

Jaime Aguayo-Silva, Fabrice Elegbede, Claude Husson, Francois-Xavier Saintonge, Benoit Marçais. Modeling climate impact on an emerging disease, the Phytophthora alni-induced alder decline. Global Change Biology, 2014, 20 (10), pp.3209 - 3221. 10.1111/gcb.12601 . hal-01268963

\section{HAL Id: hal-01268963 https://hal.science/hal-01268963}

Submitted on 4 Apr 2019

HAL is a multi-disciplinary open access archive for the deposit and dissemination of scientific research documents, whether they are published or not. The documents may come from teaching and research institutions in France or abroad, or from public or private research centers.
L'archive ouverte pluridisciplinaire HAL, est destinée au dépôt et à la diffusion de documents scientifiques de niveau recherche, publiés ou non, émanant des établissements d'enseignement et de recherche français ou étrangers, des laboratoires publics ou privés. 


\title{
Modeling climate impact on an emerging disease, the Phytophthora alni induced alder decline
}

\author{
Jaime Aguayo ${ }^{1,2}$, Fabrice Elegbede ${ }^{1,2}$, Claude Husson ${ }^{1,2}$, \\ François-Xavier Saintonge ${ }^{3}$ and Benoît Marçais ${ }^{1,2}$
}

1 INRA, UMR1136 "Interactions Arbres/Micro-organismes", INRA-Nancy, 54280 Champenoux, France.

2 Université de Lorraine, UMR1136 "Interactions Arbres/Micro-organismes", INRA-Nancy, 54280 Champenoux, France.

${ }^{3}$ Département de la Santé des Forêts, Direction régionale de l'alimentation, de l'agriculture et de la forêt Centre- SRAl, Cité administrative Coligny, 131 rue du Faubourg Bannier, 45004, Orléans Cedex 1

Corresponding author: Benoît Marçais, INRA Université de Lorraine "Interactions Arbres/Micro-organismes", IFR110 EFABA, Centre INRA de Nancy, 54280 Champenoux, France. Mail: marcais@nancy.inra.fr, Tel: [00 33] 3833940 53, Fax: [00 33] 383394069

Keywords: Emerging diseases, climate change, compartmental models, Alder, riparian ecosystems, Phytophthora

\begin{abstract}
Alder decline caused by Phytophthora alni is one of the most important emerging diseases in natural ecosystems in Europe, where it has threatened riparian ecosystems for the past 20 years. Environmental factors, such as mean site temperature and soil characteristics, play an important role in the occurrence of the disease. The objective of the present work was to model and forecast the effect of environment on the severity of alder Phytophthora outbreaks, and to determine whether recent climate change might explain the disease emergence. Two alder sites networks in NE and SW France were surveyed to assess the crown health of trees; the oomycete soil inoculum was also monitored in the NE network. The main factors explaining the temporal annual variation of alder crown decline or crown recovery were the mean previous winter and previous summer temperatures. Both low winter temperatures and high summer temperatures were unfavorable to the disease. Cold winters promoted tree recovery because of poor survival of the pathogen, while hot summer temperature limited the incidence of tree decline. An SIS model explaining the dynamics of the $P$. alni induced alder decline was developed using the data of the NE site network and validated using the SW site network. This model was then used to simulate the frequency of declining alder over time with historical climate data. The last 40 years' weather conditions have been generally favorable to the establishment of the disease, indicating that others factors may be implicated in its emergence. The model, however, showed that the climate of SW France was much more favorable for the disease than that of the Northeast, because it seldom limited the overwintering of the pathogen. Depending on the European area, climate change could either enhance or decrease the severity of the alder decline.
\end{abstract}




\section{Introduction}

Emerging infectious diseases caused by pathogenic fungi and fungal-like oomycetes severely impact crops, forests, and wild animals (Kupferschmidt, 2012). Over the past few decades, a growing number of fungal and oomycete pathogens have invaded a variety of forests communities from landscape to regional scales (Anderson et al., 2004; DesprezLoustau et al., 2007) causing rapid population declines or even species extinctions (Harvell et al., 2002), and are increasingly recognized as major threats to biodiversity (Fisher et al., 2012). Several factors have been reported to influence disease emergence, including increased disturbance by humans to forests ecosystems, intensified international trade that promotes pathogen long-distance transport and changes in climatic conditions (Anderson et al., 2004; Desprez-Loustau et al., 2007; Stenlid et al., 2011). However, pinpointing the causes that promote new disease emergences is not straightforward (Garrett et al., 2011). It is especially difficult to document the long term and progressive effects of climate change on the dynamics of disease epidemics (Jeger \& Pautasso, 2008a; Shaw et al., 2008). To demonstrate the causal role of changing climate, long-term sets of monitoring data must be available for both the environmental factors and for the disease, but this is seldom the case (Shaw et al., 2008). Moreover, many invasions may be linked to modification of the causal organism's ecological niche due to climate change (Bellard et al., 2013). Nevertheless, the role of changes in the environment and in particular in climate is beginning to be documented (Anderson et al., 2004; Bergot et al., 2004; Marçais et al., 2004; Desprez-Loustau et al., 2007; Fabre et al., 2011; Pritchard, 2011).

Mathematical models provide increasingly realistic scenarios to explain the influence of changes in temperature, precipitation and other climatic variables on plant diseases (Jeger \& Pautasso, 2008a). They can bring important insights into the epidemiology of pathogens, especially in the context of emerging diseases (Gilligan \& van den Bosch, 2008; Mundt et al., 2009). In particular, compartmental models have become a dominant theoretical approach in mechanistic modeling of plant disease, because they offer advantages in terms of analytic tractability, ease of simulation, and extensibility (Cunniffe et al., 2011). These models describe the dynamic of epidemics by splitting the studied population into compartments reflecting different disease status, and then model the transition of individuals between the compartments. Many diseases with long-range transmission are well characterized by the SIR (susceptible-infected-removed) stochastic model, where an infected host (I) can transmit the pathogen to a susceptible $(S)$ neighbor for some intervals of time, after which it is permanently recovered or removed (R) (Neri et al., 2011). Various applications of this simple approach have been developed to investigate the influence of environmental conditions on the dynamics of pathogen populations (Mundt et al., 2009).

Phytophthora alni is a pathogenic oomycete, associated with alder decline in Europe since the early 1990's (Brasier et al., 1995). The pathogen is widely spread throughout Europe (Streito et al., 2002), and has caused important losses to riparian ecosystems, where alder has an important ecological value (Claessens, 2003; Thoirain et al., 2007). The emergence of the pathogen is linked with an hybridization event between two related parental species, one of them being exotic to Europe (loos et al., 2006, Aguayo et al., 2013). While the disease was at first seen mainly as a root collar canker, Elegbede et al. (2010) showed that $P$. alni behaves more as a soil-borne pathogen causing fine root necrosis. Environmental factors play an important role in the occurrence of the disease, and several risk factors have been identified including low water flow speed, seasonal flooding by contaminated water, and fine soil texture (Jung \& Blaschke, 2004; Thoirain et al., 2007; Elegbede et al., 2010). Previous studies have also shown that high site temperature is a predominant risk factor: $P$. alni has limited survival during severe frosts which could be explained by poor oospore viability (Schumacher et al., 2006), while Thoirain et al. (2007) showed that an increase in the temperature of river water favored increased prevalence of the disease. Indeed, the pathogen is a thermophilous organism with relatively high optimal growth temperatures of $22.5-25^{\circ} \mathrm{C}$, a characteristic shared by other emerging plant 
Table 1. Characteristics of NE France sites surveyed in this study

\begin{tabular}{|c|c|c|c|c|c|c|c|}
\hline \multirow{2}{*}{$\begin{array}{l}\text { Village (Region) } \\
\text { Blamont (Meurte-et-Moselle) }\end{array}$} & \multicolumn{2}{|c|}{$\begin{array}{l}\text { Coordinates } \\
\text { (North, East) }\end{array}$} & \multirow{2}{*}{$\begin{array}{l}\text { River } \\
\text { Vesouze }\end{array}$} & \multirow{2}{*}{$\begin{array}{r}\begin{array}{r}\text { First } \\
\text { of rating }\end{array} \\
2006\end{array}$} & \multirow{2}{*}{ year } & \multirow{2}{*}{$\begin{array}{c}\begin{array}{c}\mathrm{Nb} \text { of } \\
\text { sampled alders }\end{array} \\
135\end{array}$} & \multirow{2}{*}{\begin{tabular}{l}
\multicolumn{1}{c}{$\begin{array}{c}\text { Initial } \\
\text { disease } \\
\text { prevalence }(\%)\end{array}$} \\
21.0
\end{tabular}} \\
\hline & 48.59 & 6.855 & & & & & \\
\hline Ars-sur-Moselle (Moselle) & 49.06 & 6.073 & Moselle & 2007 & & 42 & 41.0 \\
\hline Autrey (Vosges) & 48.28 & 6.696 & Mortagne & 2007 & & 76 & 45.7 \\
\hline Blies-Guersviller (Moselle) & 49.14 & 7.081 & Blies & 2007 & & 91 & 75.0 \\
\hline Damelevières (Meurthe-et-Moselle) & 48.56 & 6.385 & Meurthe & 2007 & & 62 & 56.7 \\
\hline Eloyes (Vosges) & 48.09 & 6.608 & Moselle & 2007 & & 45 & 58.1 \\
\hline Moulin-de-Hesse (Moselle) & 48.69 & 7.025 & Sarre & 2007 & & 331 & 58.9 \\
\hline Perrey (Vosges) & 48.23 & 6.373 & Avière & 2007 & & 58 & 90.2 \\
\hline Pierre-la-Treiche & 48.64 & 5.934 & Moselle & 2007 & & 131 & 43.2 \\
\hline Le Syndicat (Vosges) & 48.02 & 6.685 & Moselotte & 2007 & & 83 & 72.4 \\
\hline Budange (Moselle) & 49.27 & 6.341 & Canner & 2008 & & 73 & 30.0 \\
\hline Frapelle (Vosges) & 48.28 & 7.052 & Fave & 2008 & & 97 & 65.2 \\
\hline Haguenau (Bas-Rhin) & 48.79 & 7.831 & Moder & 2008 & & 101 & 48.4 \\
\hline Keskastel (Bas-Rhin) & 48.96 & 7.035 & Sarre & 2008 & & 59 & 86.5 \\
\hline Mignéville (Meurthe-et-Moselle) & 48.53 & 6.778 & Blette & 2008 & & 50 & 72.3 \\
\hline Niedermodern (Bas-Rhin) & 48.84 & 7.631 & Moder & 2008 & & 110 & 53.1 \\
\hline
\end{tabular}


pathogens (Brasier et al., 1995, Desprez-Loustau et al., 2007). Thus, determining the impact climatic conditions may have on the dynamics of the $P$. alni-induced alder decline on a large temporal and spatial scale is required to predict future disease dynamics. For this, we need a better understanding of the biology and persistence of the pathogen.

The objective of this work was to model the impact of climate on $P$. alni-induced alder decline in order to forecast the effect of the recent warming on the emergence of the disease. More specifically, the dynamics of $P$. alni-induced decline were surveyed on alder plots sampled on a temperature gradient in NE France over 5-6 years in order to develop an SIS model (Susceptible - infected - susceptible, a particular case of SIR model). We additionally followed the dynamics of the pathogen inoculum in soil to identify environmental factors favorable to disease development, and to better understand climate's impact on the disease. The model was then tested using data acquired on a second network located in SW France. In a last step, we used the model to assess whether recent change in the climate could explain the emergence of the disease.

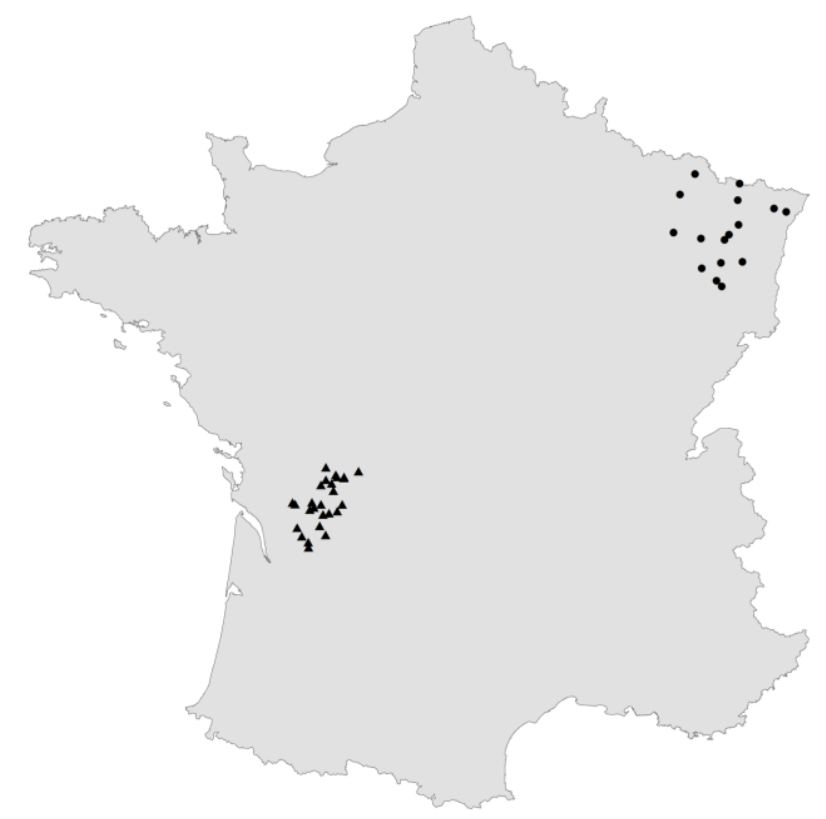

Fig.1. Localisation of studied plots. Filled circles, plots monitored for the 2006-12 period and used to develop the model. Filled triangles, plots monitored by the Département de la Santé des Forêts for the 1998-03 period and used for model testing.

\section{Materials and Methods}

\section{Study sites}

Sixteen alder survey plots were established in the Lorraine and Alsace regions in NE France (Fig. 1). The plots were selected to span a gradient of temperatures and to represent high disease prevalence levels (proportion of diseased trees) in order to minimize the influence of inoculum availability. Characteristics of selected plots are given in Table 1. Presence of $P$. alni subsp alni was confirmed in the 16 sites, either by isolation or by baiting. Neither $P$. alni subsp uniformis nor $P$. alni subsp multiformis were recovered on the sites. Plots at least $250 \mathrm{~m}$ long were set up along the river on the 2 banks. All alders above $1.3 \mathrm{~m}$ high present within a $10 \mathrm{~m}$ zone of the river banks were selected, marked and mapped. The length of bank surveyed was extended until at least 40 alders were selected. Altogether, 
1426 alders were monitored. One plot was established in 2006, 9 in 2007 and 6 in 2008. Water stream speed was recorded once a year in summer (between July and September) for each survey plot using a current meter. Each year, water stream speed was measured in the plots at 4-10 different locations distant from each other by at least $10 \mathrm{~m}$ to cover the entire length of the plot.Additionally, soil properties for each plot site, $\mathrm{pH}$, soil texture, organic carbon $(\mathrm{C})$, total nitrogen $(\mathrm{N})$, were obtained from soil sampled at the base of two randomly chosen alder trees. Two to four soil samples were taken per tree with a soil borer at 10-50 cm from the stem base. Litter was removed and $\approx 500 \mathrm{~g}$ of soil were pooled in a plastic bag and stored at $4^{\circ} \mathrm{C}$ until processed. Soil analyses were carried out by the Laboratoire d'Analyse des Sols d'Arras (http://www5.lille.inra.fr/las) for $\mathrm{pH}$ (water method), total carbon (C) and total nitrogen (N) content (NF ISO 10694 and NF ISO 13878). Climatic data, mean air temperatures, rain and potential evapotranspiration (PET) per 10-days periods, were obtained from the nearest Météo-France meteorological stations with data over 2006-12 period. The meteorological stations were $4-25 \mathrm{~km}$ from the sites.

\section{Survey procedure}

In each plot, all alder trees reaching a height of $1.30 \mathrm{~m}$ were sampled and mapped between the years of establishment (2006 to 2008) and 2012. For each sampled alder, information was collected on the year of recruitment to the study, distance to the river, and number of stems (for coppiced trees). Tree diameters were measured at $1.30 \mathrm{~m}$ above ground level (diameter at breast height, dbh) at 2-year intervals from 2006 to 2012 . The basal area of the trees was computed from the stem diameter measurements. For coppiced trees, the number of stems above $2 \mathrm{~cm}$ dbh was determined, and the $\mathrm{dbh}$ of the three biggest stems was measured. The basal area was computed from those data using a relationship established by Elegbede et al. (2010). Annually, between May and June, the crown health status of each tree was recorded on a 1-4 scale, with 1 indicative of healthy foliage (leaves with normal size and color and dense crown); 2 of a defoliation of 10 to $50 \%$, with small and yellowish leaves; 3 of a defoliation of $>50 \%$, with small yellowish leaves and dead branches; and 4 of tree dead (no leaves, bark dead at the trunk level).

\section{Soil inoculum estimation}

Soil sampling. From 2009 to 2012, six large alder trees per site were sampled two to three times per year, in May-June, July-August and September-October (96 trees at each sampling). Trees were not sampled in autumn in 2009 and in summer in 2012. Alder trees with relatively healthy crowns (rated as 2) were selected because they were shown by Elegbede et al. (2010) to have the highest level of $P$. alni inoculum in the soil at the trunk base. Three to four soil cores, $5 \mathrm{~cm}$ in diameter and $15-20 \mathrm{~cm}$ depth, were sampled with a sterilized soil borer at the base of each tree, at $1 \mathrm{~m}$ from the collar. Samples were sealed in plastic bags and kept cool at $4^{\circ} \mathrm{C}$ until processed in the laboratory.

Baiting procedure. Baiting was performed as described by Elegbede et al. (2010). A 200 $\mathrm{ml}$ subsample of soil was covered with $500 \mathrm{ml}$ of distilled water in a plastic container. Baiting was performed using three well-developed similar-sized leaves of rhododendron cv. Cunningham's white, which were floated on the surface. The surface area of the rhododendron leaves used as baits was estimated from it length and width and recorded. Plastic containers were incubated in the dark at $20^{\circ} \mathrm{C}$ in a temperature-controlled chamber for 3 days. Then, the leaves were removed, dried and kept at $4^{\circ} \mathrm{C}$ until processing. Necrotic spots induced by Phytophthora spp. for each bait leaf were counted. A subsample of up to 15 necrotic spots per soil sample was removed with a sterilized scalpel for $P$. alni detection by PCR.

Inoculum estimation. Necrotic spots were individually placed in 96-wells plates for DNA extraction. Negative and positive controls were as well included in each plate. DNA extraction was performed using the Dneasy96 plant kit (Qiagen, Courtaboeuf, France) 
following the manufacturer's instructions. Specific $P$. alni primers T-PAU-F (CGG-CCG-TTGACA-TGT-TTA), T-PAU-R (GGG-CGC-CAT-ACA-AAA-TC) and a Taqman ${ }^{\mathrm{TM}}$ probe, T-PAU$P$ (TCG-GGT-TTT-GTT-TGG-TGC-TGT) were designed on the basis of the single copy mitochondrial gene GPA1 (loos et al., 2006) to amplify a 81 bp fragment from $P$. alni (either $P$. alni subsp alni or $P$. alni subsp uniformis). The fluorogenic probe T-PAU-P was labeled at the 5' end with the fluorescent reporter dye JOE ${ }^{\mathrm{TM}}$ and the 3' end was modified with the quencher dye BHQ-1 ${ }^{\mathrm{TM}}$. Real-time PCR amplifications were performed using the $\mathrm{qPCR} \mathrm{R}^{\mathrm{TM}}$ Mastermix No ROX (Eurogentec, Seraing, Belgium), containing $1 \mathrm{X}$ reaction buffer, $0.15 \mathrm{U}$ of Uracil-N-Glycosylase (UNG, Eurogentec, Angers, France), $0.3 \mu \mathrm{M}$ of the respective forward and reverse primer, $0.1 \mu \mathrm{M}$ of the dual-labeled probe, $2 \mu \mathrm{l}$ of template DNA and molecular biology grade water was added to $15 \mu$ l. The real-time PCR cycle conditions included an initial UNG activation step for $2 \mathrm{~min}$ at $50^{\circ} \mathrm{C}$, a Taq polymerase activation step for $10 \mathrm{~min}$ at $95^{\circ} \mathrm{C}$ followed by 40 cycles of denaturation for $15 \mathrm{~s}$ at $95^{\circ} \mathrm{C}$ and annealing / elongation for 50 $s$ at $62^{\circ} \mathrm{C}$. PCR reactions were carried out with a Stratagene Mx3005P using the Mx-Pro software (Agilent, Les Ulis, France). Presence of $P$. alni in the target necrotic spots was estimated by the presence/absence of amplification curves after fixing a threshold established in the exponential part of the amplification curve.

\section{Data analysis}

\section{Estimation of $P$. alni soil inoculum}

The number of necrotic lesions induced by $P$. alni on the rhododendron leaves after baiting was used as a measure of soil inoculum level. It was estimated as the total number of necrotic lesions multiplied by the proportion of PCR analyzed lesions in which P. alni was detected. When dealing with count data, the Poisson regression model is normally used. However, the data contained an excess of zeros, and the best fitting model was zero-inflated Poisson (ZIP, see Elegbede et al., 2010). Indeed, absence of detection of $P$. alni at the base of a tree may indicate real absence of inoculum, but could be a sampling error, linked to inadequate sampling and/or detection by baiting. ZIP models assume that the data result from a mixture of two independent data generation process: the first represent the detection errors and will generate only zeros, while the second is a Poisson data-generating process. The result of a Bernoulli trial is used to determine which of the two processes will generate an observation. Thus, a logistic regression model was used to fit the probability $(p)$ of $P$. alni detection in the soil, and a log-linear model with the rhododendron leaf surface as an offset was used to predict the mean number of necrotic lesions on bait leaves $(\lambda)$,

$$
\begin{aligned}
& \log \left(\lambda_{i}\right)=\log \left(\operatorname{surf}_{i}\right)+x_{i}^{t} \beta \\
& \log i t\left(p_{i}\right)=\log \left[p_{i}\left(1-p_{i}\right)\right]=W_{i}^{t} \gamma
\end{aligned}
$$

Where surf represents the area of rhododendron leaves used as baits, $x_{i}^{t} \beta$ and $W_{i}^{t} \gamma$ are linear predictors, $\beta=\left(\beta_{1}, \ldots, \beta_{q}\right)$ and $\gamma=\left(\gamma_{1}, \ldots, Y_{r}\right)$ are vectors of regression associated with the explicative variables $X_{i}=\left(X_{i 1}, \ldots, X_{i q}\right)$ and $W_{i}=\left(W_{i 1}, \ldots, W_{i r}\right)$. We included in all models as explanatory variables the season (spring, summer or autumn), mean temperature and total precipitation of the 10-days preceding the baiting, mean temperature in the winter preceding the baiting (November to March), and site variables such as soil $\mathrm{pH}$, texture (clay / sand ratio) and carbon / nitrogen ratio.

The model was fitted in a Bayesian framework under WinBUGS 1.4.3. Non-informative priors were assigned to the model parameters according to a normal distribution $\mathrm{N}(0$, $1 \mathrm{e}+06$ ). The model was fitted with a burn-in of 30000 , for 200000 iterations with a thinning of 20. Three parallels chains with different initial parameter values were run and convergence was checked by a Gelman-Rubin test ( $R_{\text {hat }}$ were close to 1$)$. 


\section{Crown disease incidence}

Tree decline incidence, i.e. the likelihood that a tree not declining in year $t$ declines in year $t+1$, and tree recovery, i.e. the likelihood that a tree declining in year $t$ is not rated as declining in year $t+1$, were analyzed by logistic regression using as explanatory variables the mean temperature in summer of year $n-1$ (July-August), the mean temperature in winter of year n-1 or n-2 (November-March) and all sites variables (speed of the river stream, soil pH, carbon / nitrogen ratio and soil texture estimated by the clay / sand ratio). Preliminary analysis showed that the dynamic of tree crown status responded better to climate of the previous year than to the current year, probably because trees were rated early in the vegetation season, in May-June.

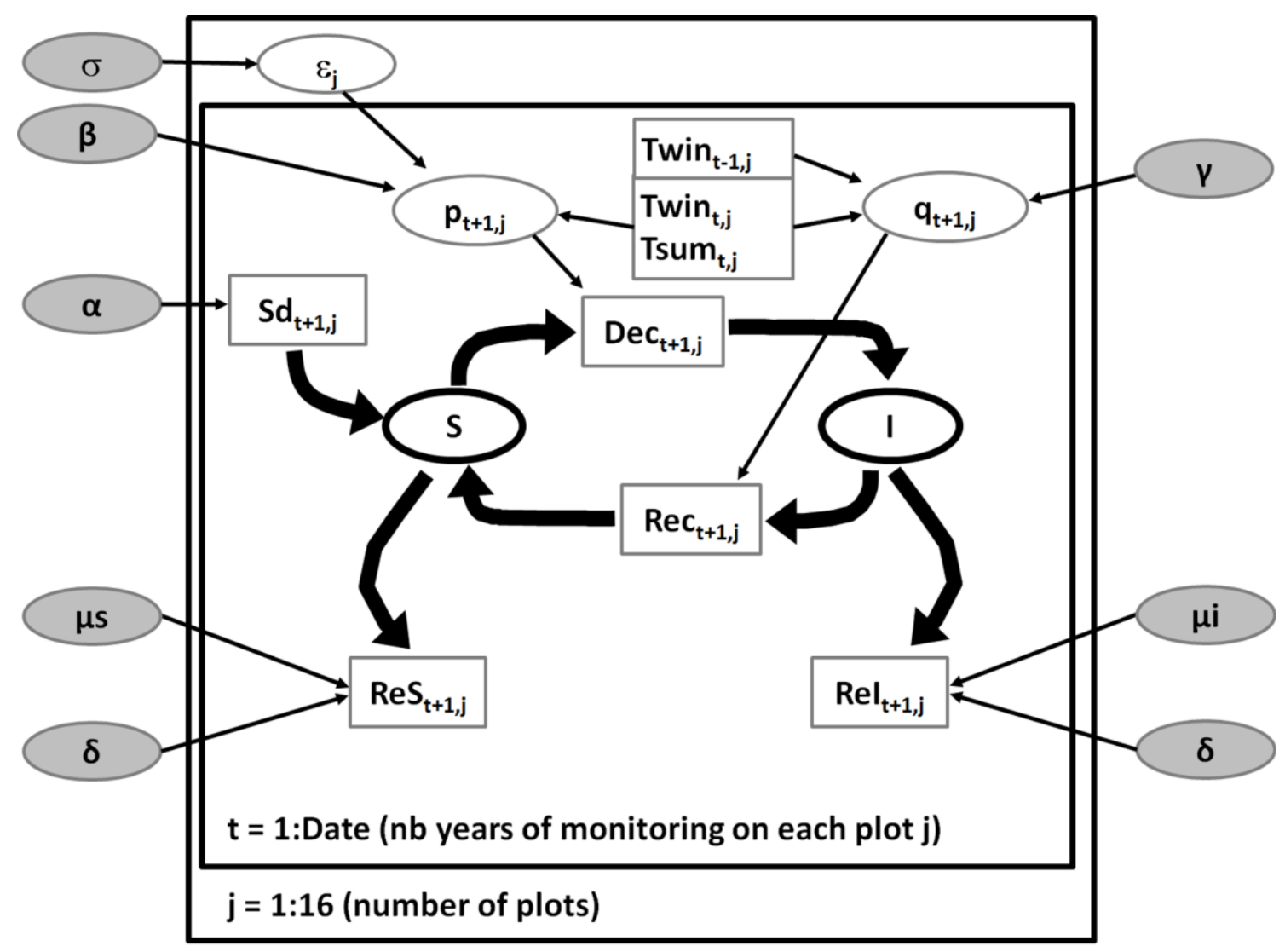

Fig. 2. SIS model used to simulate dynamic of $P$. alni induced alder decline on the monitored plots. The model encompasses 2 compartments i.e. non-declining (S) and declining (I) trees. Transitions between the compartments for plot $\mathrm{j}$ are $\mathrm{Dec}_{t+1, \mathrm{j}}$, trees healthy in year $t$ that decline the following year, $\operatorname{Rec}_{t+1, j}$, declining trees that recover in year $n+1$, $\operatorname{ReS}_{t+1, j}$ and $R I_{t+1, j}$, non-declining (S) and declining (I) trees that disappear or die in year $t+1$ and $\mathrm{Sd}_{t+1, j}$, the number of, new seedlings arriving in year $t+1$. Model parameters are $p_{t+1, j}$ and $q_{t+1, j}$, respectively the decline and recovery rate that depend on mean winter and mean summer temperature of previous years $\left(\operatorname{Twin}_{t-1, j}, \operatorname{Twin}_{\mathrm{t}-2, \mathrm{j}}\right.$ and Tsum $\left._{\mathrm{t}-1, \mathrm{j}}\right), \alpha$, the rate of arrival on the plots of new seedlings, mortality rate for nondeclining $(\mu \mathrm{s})$ and declining trees $(\mu \mathrm{i})$ and $\delta$, the rate at which both declining and nondeclining trees disappear. The decline rate, $p_{t+1, l}$ additionally depends on a random site effect.

A SIS model was defined to estimate the dynamic of alder decline on the studied plots. Two compartments were defined: i. susceptible trees, $S$, were the non-declining trees (trees 
with crown rated 1) and ii. infectious trees, I, were the declining trees (trees with crown rated 2-3). Only declining trees were assumed to be infectious. The existence of asymptomatic (non-declining) alders which are nonetheless infected and infectious has been documented (Elegbede et al., 2010) but they were not taken into account as we have no data to estimate their frequency. Dead trees were considered no longer infectious, as $P$. alni survives in soil in the absence of a living host for less than a year (Jung \& Blaschke, 2004; Elegbede et al., 2010). The model estimates the yearly transition between the compartments (Fig. 2) which are Dec, the number of new decline cases; Rec, the number of declining trees that recover; $\operatorname{ReS}$ and Rel, the number of respectively non-declining $S$ and declining I trees that die or disappear; and Sd, the arrival of new seedlings in the plot (annual recruitment). $\operatorname{Dec}_{t+1, j}$, the number of $S$ trees in plot $j$ and year $t$ that decline in year $t+1$, was estimated from the proportion of $I$ trees in year $t$ and from a year-dependent decline rate $p_{t+1, j}$. The rate $p_{t+1, j}$ depended on the mean temperature of the previous winter $\operatorname{Twin}_{t, j}$ and summer $\operatorname{Tsum}_{t, j}$ and on a random plot effect $\varepsilon_{j}$ that followed a normal law $N(0, \sigma)$. Dec $c_{t+1, j}$ was considered to follow a Poisson law of parameter Dec. $m_{t+1, j}$ :

(1) Dec. $m_{t+1, j}=p_{t+1, j} \times\left(I_{t, j} /\left(I_{t, j}+S_{t, j}\right)\right) \times S_{t, j}$ with Logit $\left(p_{t+1, j}\right)=\beta_{1}+\beta_{2} \times \operatorname{Twin}_{t, j}+\beta_{3} \times\left(\operatorname{Tsum}_{t, j}-\beta_{4}\right)^{2}+\varepsilon_{j}$

Trees recovered (when declining in year $t$ and non-declining in year $t+1$ ) at a rate $q_{t+1, j}$ that depends on $\mathrm{Twin}_{\mathrm{t}, \mathrm{j}}$, $\mathrm{Twin}_{\mathrm{t}-1, \mathrm{j}}$ and $\mathrm{Tsum}_{\mathrm{t}, \mathrm{j}}$ the mean temperatures of the two previous winters and of the previous summer. It was presumed that climate could have an effect over several years if it affected inoculum in the soil, and preliminary analysis showed that this was indeed the case for winter temperature. $\operatorname{Rec}_{t+1, j}$ the number of trees that recover in year $t+1$ and plot $\mathrm{j}$ was considered to follow a Poisson law of parameter Rec. $\mathrm{m}_{\mathrm{t}+1, \mathrm{j}}$ :

(2) Rec. $m_{t+1, j}=q_{t+1, j} \times I_{t, j}$

$$
\begin{aligned}
& \text { with } \mathrm{q}_{\mathrm{t}+1, \mathrm{j}}=1-\left(\mathrm{d}_{\mathrm{t}+1, \mathrm{j}} \times \mathrm{su}_{\mathrm{t}+1, \mathrm{j}}\right) \\
& \text { and Logit }\left(d_{t+1, j}\right)=\gamma_{1}+\gamma_{2} \times \operatorname{Twin}_{t, j}+\gamma_{3} \times \operatorname{Twin}_{t-1, j} \\
& \operatorname{Logit}\left(\mathrm{su}_{\mathrm{t}+1, j}\right)=\mathrm{V}_{4}+\mathrm{V}_{5} \times \operatorname{Tsum}_{\mathrm{t}, \mathrm{j}}
\end{aligned}
$$

The dependence of $q_{t+1, j}$ toward climate was chosen so the trees recover whenever either winters temperatures are cold or summer temperatures are hot enough.

The rate of alder death was assumed to be independent of both the year and the plot, and to be different for non-declining $S$ and declining I trees ( $\mu$ s and $\mu \mathrm{i})$. Indeed, a preliminary analysis showed that declining I trees death rate did not depend on either winter or summer temperature. Trees may drop out of the sample for reasons independent from $P$. alni (e.g., from falling in the river with the erosion of a piece of the bank or from being cut by a fisherman or a beaver); we refer to these as disappeared. S and I trees disappeared at an identical rate $\delta$ independent of the year and plot. The number of trees that died or disappeared in plot j was $\operatorname{ReS}_{t+1, j}$ and $\operatorname{Rel}_{t+1, j}$ respectively for $S$ and I trees, and followed a Poisson law of parameter ReS. $m_{t+1, j}$ and Rel. $m_{t+1, j}$ :

(3) $\operatorname{ReS} \cdot m_{t+1, j}=(\mu s+\delta) \times S_{t, j}$

(4) Rel. $m_{t+1, j}=(\mu i+\delta) \times I_{t, j}$

Finally, new seedlings arrived on the plots at a rate $\alpha$. The number of new seedlings arriving on plot $\mathrm{j}$ in year $\mathrm{t}+1, \mathrm{Ns}_{\mathrm{t}+1, \mathrm{j}}$, followed a Poisson law of parameter $\mathrm{Ns} . \mathrm{m}_{\mathrm{t}+1, \mathrm{j}}$ :

(5) Ns. $m_{t+1, j}=\alpha \times\left(S_{t, j}+I_{t, j}\right)$,

The numbers of trees in the two compartments were modelled from the numbers in the previous year and from the transitions between compartments:

$$
\begin{aligned}
& S_{t+1, j}=S_{t, j}+N s_{t+1, j}+\operatorname{Rec}_{t+1, j}-\operatorname{Dec}_{t+1, j}-\operatorname{ReS}_{t+1, j} \\
& I_{t+1, j}=I_{t, j}+D e c_{t+1, j}-\operatorname{Rec}_{t+1, j}-\operatorname{ReI}_{t+1, j}
\end{aligned}
$$


The model was fitted in a Bayesian framework under WinBUGS 1.4.3. Non-informative priors were assigned to most of the model parameters. $\mu \mathrm{s}, \mu_{\mathrm{i}}, \delta$, and $\alpha$ were assigned a lognormal distribution $L N(0,1 e+04)$ while $\beta_{1}, \beta_{2}, \beta_{3}, \gamma_{1}, \gamma_{2}, \gamma_{3}, \gamma_{4}$ and $\gamma_{5}$ were assigned a Normal distribution $\mathrm{N}(0,1 \mathrm{e}+06)$. A moderately informative prior was given to the parameter $\beta_{4}$, which represents the optimal temperature for induction of decline by $P$. alni. On the grounds that the optimal temperature for $P$. alni growth in vitro is about $22^{\circ} \mathrm{C}$ (Brasier et al., 1995), the prior for $\beta_{4}$ was assigned a Normal distribution $N(22,5)$. The model was fitted with a burn-in of 1500000 , for 3000000 iterations with a thinning of 100 . Three parallel chains with different initial parameter values were run and convergence was checked by Gelman-Rubin test $\left(R_{\text {hat }}\right.$ were close to 1).

\section{Test of the developed model with a cross-validation dataset}

To test the model described in the previous section, we used data from a network of 26 plots located in the Charente area in SW France (Fig 1), which were monitored from 1998 to 2003 by the French forest health survey system, the Département de la Santé des Forêts. Altogether, about 900 trees were marked and annually rated for crown decline with a rating similar to the one described in the previous section (25 to 45 Alnus glutinosa per plots). Half of the plots were not rated in 2001. No new alder was included in the monitored sample after plot establishment. The decline symptoms were very similar to $P$. alni-induced decline, but the presence of $P$. alni was tested and confirmed on only 4 of the sites. Climate data, the mean temperature in winter (November to March) and summer (July to August), were collected in 1998-2003 at the closest Safran grid point. Safran data are meteorological data from Météo-France computed at an hourly basis on an $8 \times 8 \mathrm{~km}$ grid throughout France (Quintana-Segu et al., 2008); they were available until 2008. On this plot network, the trees were rated in autumn, late in the season, so no lag was used for the temperature years. Beginning from the number of trees declining (I, crown rating of 2 or 3 ) or not declining (S, crown rating of 1) recorded in 1998, and using the Safran data, the change in number nondeclining $S$ and declining I alder were simulated for each plot from 1999 to 2003. All simulations were performed using the $\mathrm{R}$ library DeSolve. The quality of model outputs was then tested by plotting the simulated decline prevalence, i.e. frequency of declining alder, against the observed one.

\section{Simulation of past $P$. alni-induced alder decline dynamics}

We used our model to estimate a capacity for disease establishment at 38 sites, based on temperature data of the past 40 years. We then modelled disease dynamics in these sites. This was done for the 38 Safran points the closest to the monitored sites (16 for the Rhin-Meuse area and 22 for the Charente Area). The annual decline rate $p_{t, j}$ and recovery rates $\mathrm{q}_{\mathrm{t}, \mathrm{j}}$ were computed for each Safran point for the 1970-2008 period using the parameters fitted in the previous section. An annual dynamic of the decline from a low disease level was simulated with an initialization of the model with 199 non-declining alder $\left(\mathrm{S}_{\mathrm{j}}\right)$ and one declining alder $\left(\mathrm{I}_{\mathrm{j}}\right)$ each year, and the use of the computed $\left(\mathrm{p}_{\mathrm{t}, \mathrm{j}}\right.$ and $\left.\mathrm{q}_{\mathrm{t}, \mathrm{j}}\right)$ or fitted $(\mu \mathrm{s}, \mu \mathrm{i}, \delta$ and $\alpha$ ) rates. Each site's capacity for disease establishment was characterized by the frequency of years within a 5-year period with an increase in disease prevalence from the low-level prevalence of $0.5 \%$.

To assess the suitability of climate for $P$. alni development in the Rhin-Meuse and Charente areas, in NE and SW France, respectively, we next simulated disease prevalence over a period of 40 years. For the 38 Safran grid points, dynamics were simulated using the annual decline and recovery rates computed in the previous step. The simulation was initiated in 1970 with a plot of 200 alder with one declining tree $\left(I_{1, j}=1\right)$, and disease prevalence was simulated from 1970 to 2008. To avoid disease extinction in unfavorable conditions, a small recurrent arrival of declining alder was included at $10 \%$ of the recruitment of non-declining alders. Simulations were performed using the R library DeSolve. 


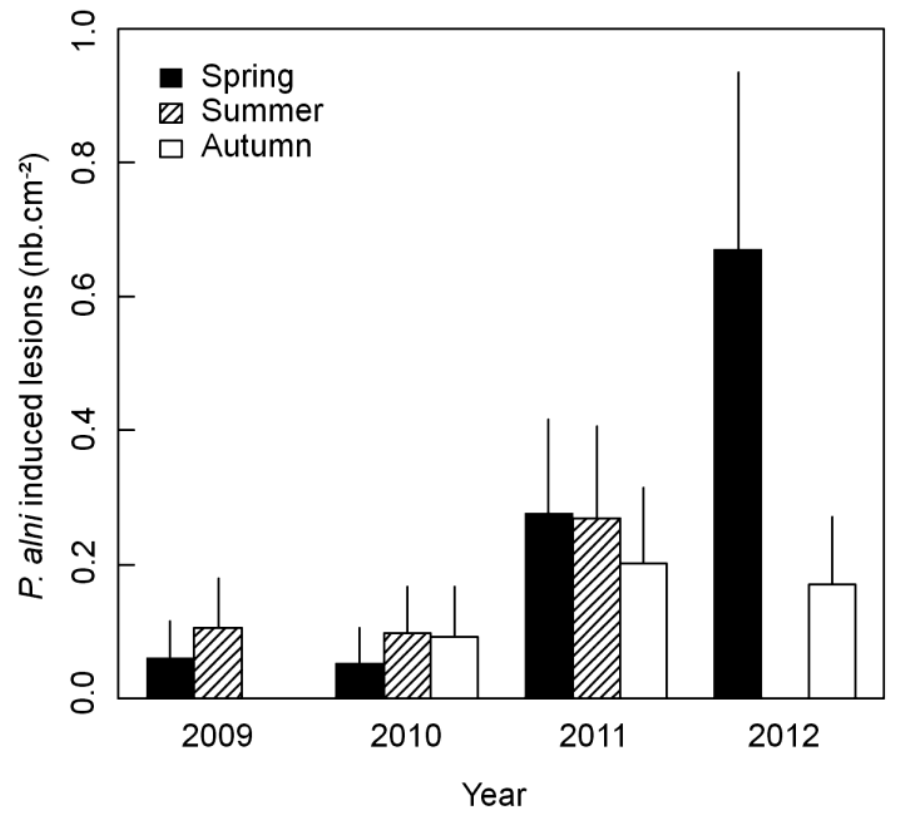

Fig. 3. Occurrence of $P$. alni inoculum in the soil at the base of alder trees across time. Soil inoculum was estimated by baiting on rhododendrons leaves (6 trees per sites at each date).

\section{Results}

\section{Estimation of $P$. alni soil inoculum}

In each of the 16 sites, presence of $P$. alni could be demonstrated by baiting on the majority of the studied trees. Altogether, the pathogen was successfully baited on $82 \%$ of the 135 tested trees. Soil inoculum, estimated as the number of lesions induced by $P$. alni per unit area of bait leaves, was very different across the 4 years, most markedly in spring (Fig. 3). Accordingly, the main factors that influenced the level of soil inoculum were the season (likelihood Chisq $=860$, pvalue $<0.001$ ) and the mean temperature of the previous winter (likelihood Chisq $=3590$, pvalue $<0.001$ ); these 2 factors significantly interacted (likelihood Chisq $=1420$, pvalue $<0.001$ ). Indeed, figure 4 shows that the springtime level of $P$. alni inoculum in the soil strongly increased with the mean temperature of the previous winter, while $P$. alni baiting in summer and in autumn did not increase after mild winters.

Other factors affected the level of $P$. alni soil inoculum, although with far less importance. The number of lesions per unit area decreased significantly when the mean temperature of the 10day period preceding sampling was high (pvalue $=0.001$ ) and was significantly related to the soil $\mathrm{pH}$ (pvalue $<0.001$ ). The square of soil $\mathrm{pH}$ also had a significant relationship with the number of lesions per unit area (pvalue $<0.001$ ), with an optimum $\mathrm{pH}$ at $6.5 \pm 0.1$. By contrast, total rain during the 10 -days period preceding sampling (pvalue $=0.908$ ), soil clay / sand ratio ( $p$ value $=0.966$ ) and soil carbon / nitrogen ratio (pvalue $=0.253$ ) were not related to the number of $P$. alni lesions per unit area. 

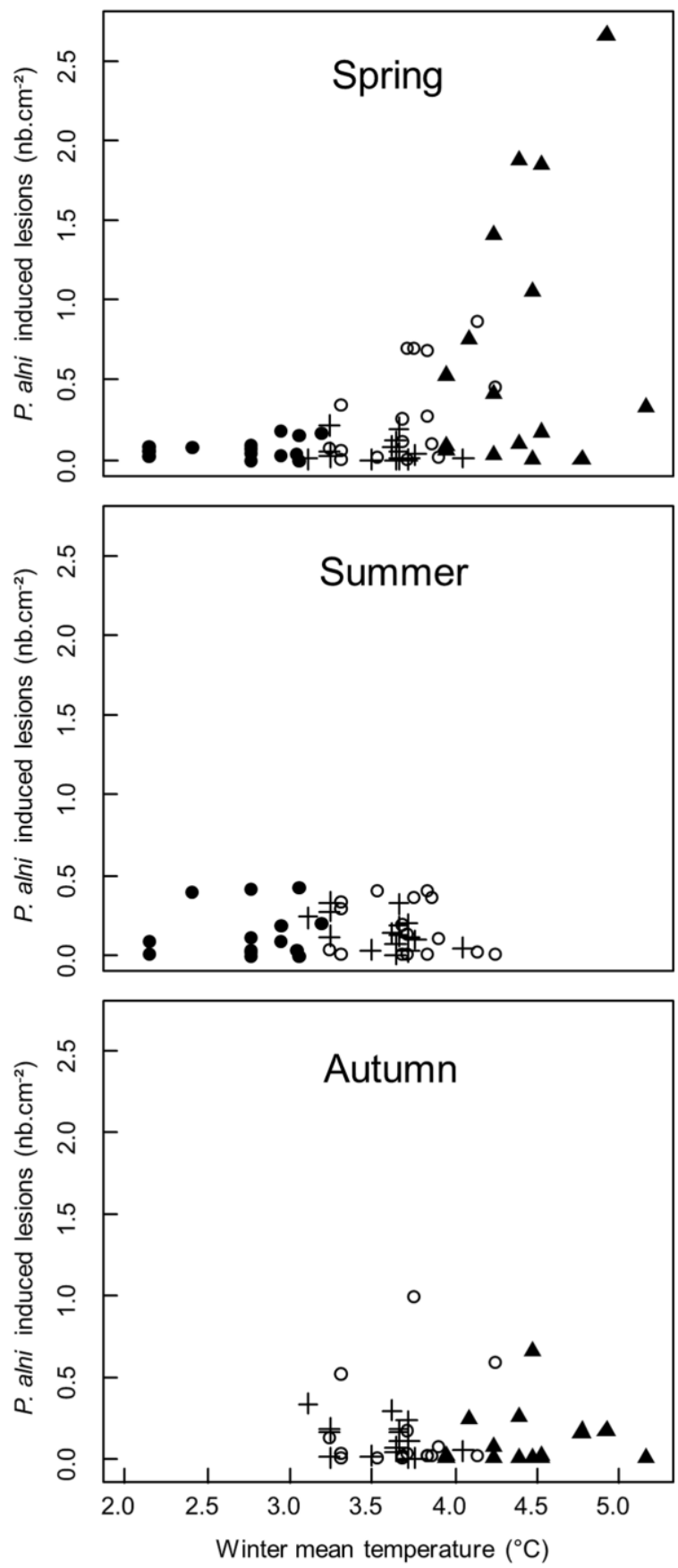

- 2009 + 2010 ○ 2011 \ 2012

Fig. 4. Relationship between $P$. alni inoculum in the soil at the base of alder trees in the 3 sampling seasons and mean temperature of the previous winter. Soil inoculum was estimated by baiting on rhododendrons leaves ( 6 trees per sites at each date). 
Table 2. Parameters of the fitted model

\begin{tabular}{llllll}
\hline Parameter & mean & sd & $2.5 \%$ & $97.5 \%$ & $R_{\text {hat }}$ \\
\hline$\beta_{1}$ & -0.63 & 1.31 & -2.91 & 2.24 & 1.02 \\
$\beta_{2}$ & 0.59 & 0.15 & 0.31 & 0.88 & 1.01 \\
$\beta_{3}$ & -0.19 & 0.05 & -0.31 & -0.10 & 1.02 \\
$\beta_{4}$ & 15.1 & 1.02 & 12.7 & 16.8 & 1.05 \\
$\gamma_{1}$ & -5.63 & 1.02 & -7.64 & -3.80 & 1.10 \\
$\gamma_{2}$ & 1.17 & 0.17 & 0.88 & 1.51 & 1.08 \\
$\gamma_{3}$ & 1.18 & 0.20 & 0.82 & 1.58 & 1.08 \\
$Y_{4}$ & 12.3 & 1.41 & 9.7 & 14.9 & 1.02 \\
$Y_{5}$ & -0.50 & 0.08 & -0.66 & -0.37 & 1.02 \\
$\mu S$ & 0.005 & 0.001 & 0.003 & 0.008 & 1.00 \\
$\mu i$ & 0.023 & 0.002 & 0.018 & 0.028 & 1.00 \\
$\delta$ & 0.019 & 0.002 & 0.016 & 0.022 & 1.00 \\
$\alpha$ & 0.016 & 0.002 & 0.013 & 0.019 & 1.00 \\
$\sigma$ & 0.88 & 0.26 & 0.48 & 1.49 & 1.01 \\
\hline
\end{tabular}

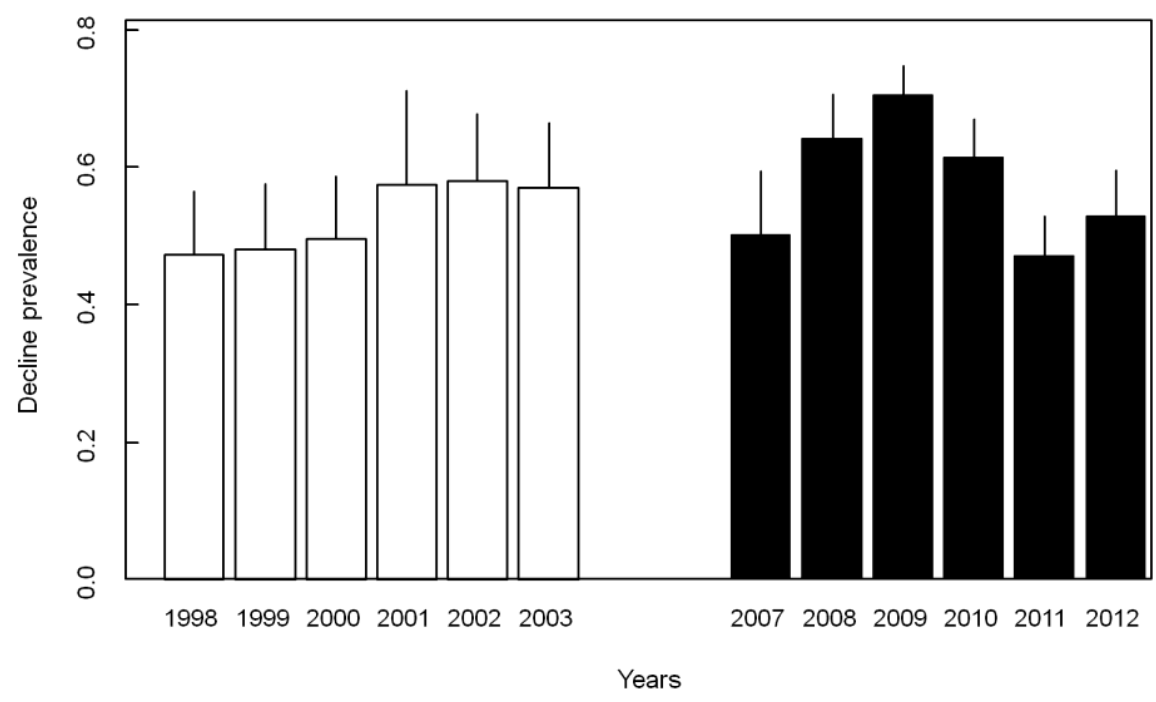

Fig.5. Alder decline prevalence in the 2 monitored plots networks. Empty bars, network of the Charente area, located in SW France, solid bars, network of the Rhin-Meuse area, located in NE France.

\section{Incidence of decline in the Rhin-Meuse area}

The observed crown decline prevalence dynamics showed a clear pattern through the years 2007-2012 (Fig. 5). Prevalence increased from 2007 to 2009, and then decreased from years 2010 to 2012. The decreasing prevalence of decline was due to the recovery of many declining alders, i.e. trees with a crown declining in year $t$ and healthy in year $t+1$. Temporal variation of prevalence could be explained mainly by mean temperatures in the previous winter and summer (with a one year lag, linked to the assessment early in the growth season). Mild winter temperatures were positively related to the incidence of crown decline and negatively related to the recovery of declining trees (respective odd ratio of 1.38 
and 0.68 with confidence limits of $1.30-1.47$ and $0.63-0.73$, respective Likelihood Chisq of 122.8 and 120.3 , both pvalue $<0.001$, Fig.6a and $6 \mathrm{~b}$ ). The recovery of declining trees was significantly linked to the mean winter temperature 2 years before the health assessment (odd ratio of 0.75 , confidence limits of 0.70-0.81, Likelihood Chisq $=58.1$, pvalue $<0.001$ ). By contrast, the incidence of crown decline significantly decreased with increasing summer temperature (odd ratio of 0.57 , confidence interval of $0.53-0.61$, Likelihood Chisq $=267.7$, pvalue $<0.001$ ) while recovery of declining alder trees increased after hotter summers (odd ratio of 1.52, confidence interval of 1.39-1.65, Likelihood Chisq $=53.9$, pvalue $<0.001$ ). None of the measured soil properties (soil pH, clay / sand or carbon / nitrogen ratio) was significantly linked to either tree recovery or decline, nor were water stream speed, summer rainfall, nor water balance (precipitation minus potential evapo-transpiration, results not shown, $p$-values in the 0.1-0.9 range). Consequently, the SIS model was built taking into account only the mean winter and summer temperatures and none of the site properties (soil characteristics or water stream speed).
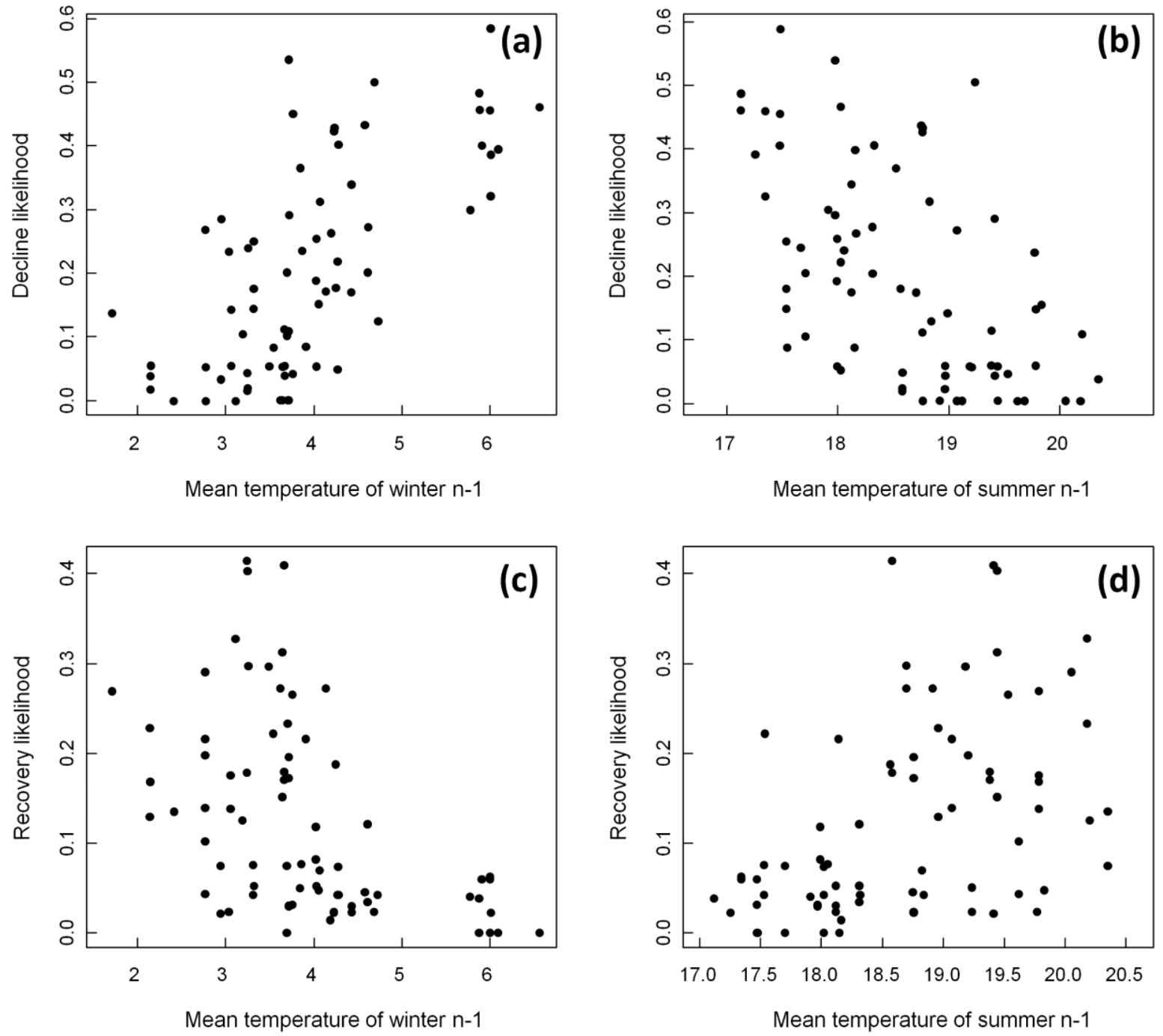

Fig.6. Decline and recovery of alders on the monitored Rhin-Meuse plots in relation with temperature of the previous winter (a and c, November to March) or previous summer ( $b$ and d, July to August). Because trees were rated very early in the season, there is a one year-lag in the influence of temperature on tree crown status. 
Parameter estimates of the model are given in Table 2. All coefficients were statistically significant. $R_{\text {hat }}$ values close to 1 (values from 1.00-1.10) indicated that the model converged. As expected, the rate at which trees declined $\left(p_{t+1, i}\right)$, and at which declining trees recovered $\left(\mathrm{q}_{t+1, i}\right)$ were significantly linked to the mean temperatures of the previous winter and summer. The parameters $\beta_{2}, \beta_{3}, \beta_{4}, \gamma_{2}, \gamma_{3}$, and $\gamma_{5}$ were all significantly different from 0 (Table 2). The optimal temperature for decline induction was found to be quite low, at $15.1^{\circ} \mathrm{C}$. The random site factor introduced significant variability, with a variance $\sigma$ of $0.48-1.49$. The modelled mortality was much higher for I trees compared to $S$ trees $(0.003-0.008$ versus $0.018-0.028)$. The decline prevalence predicted by the model was well related to the one observed (Fig. 7a).
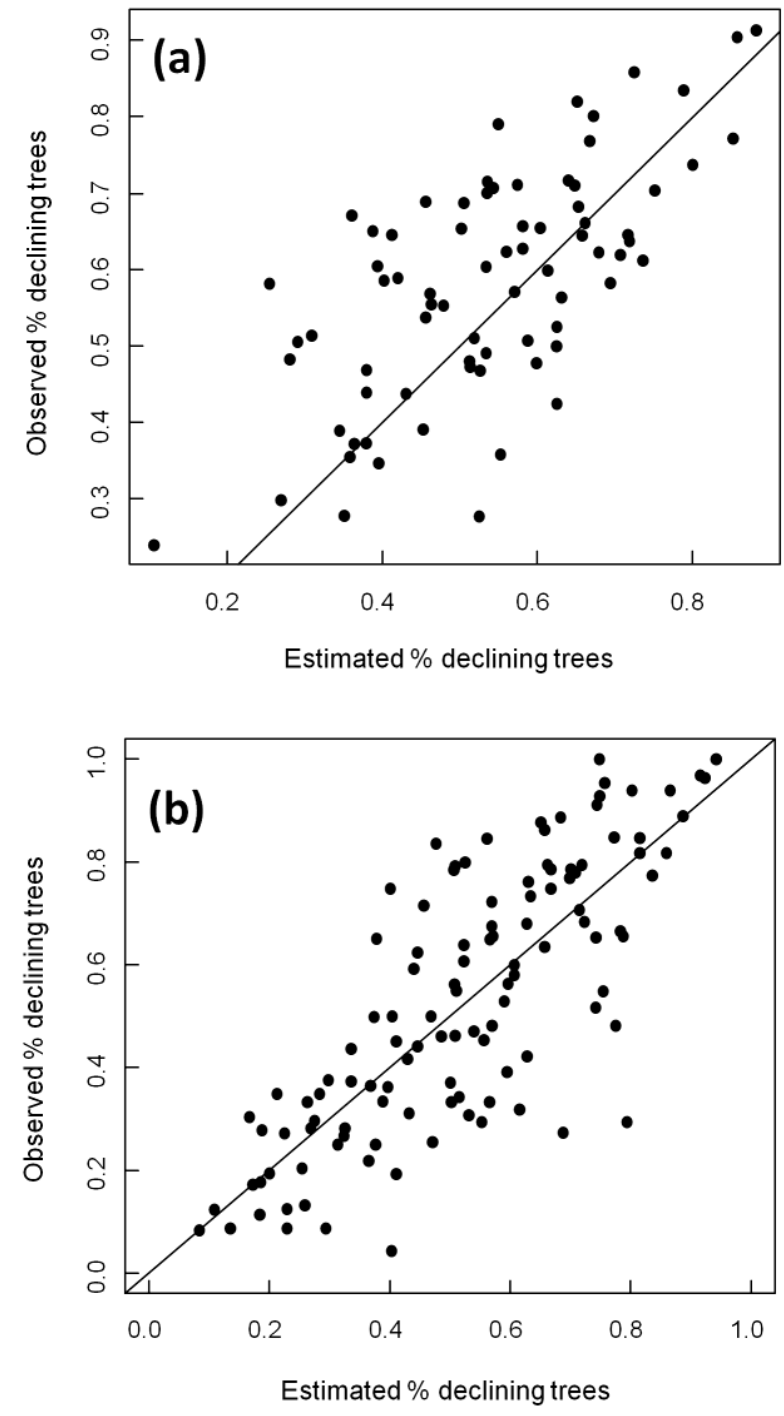

Fig.7. Output of the SIS model: predicted and observed annual decline prevalence for the construction data set (a, 16 plots from NE France) and cross-validation data set (b, 26 plots from SW France). 

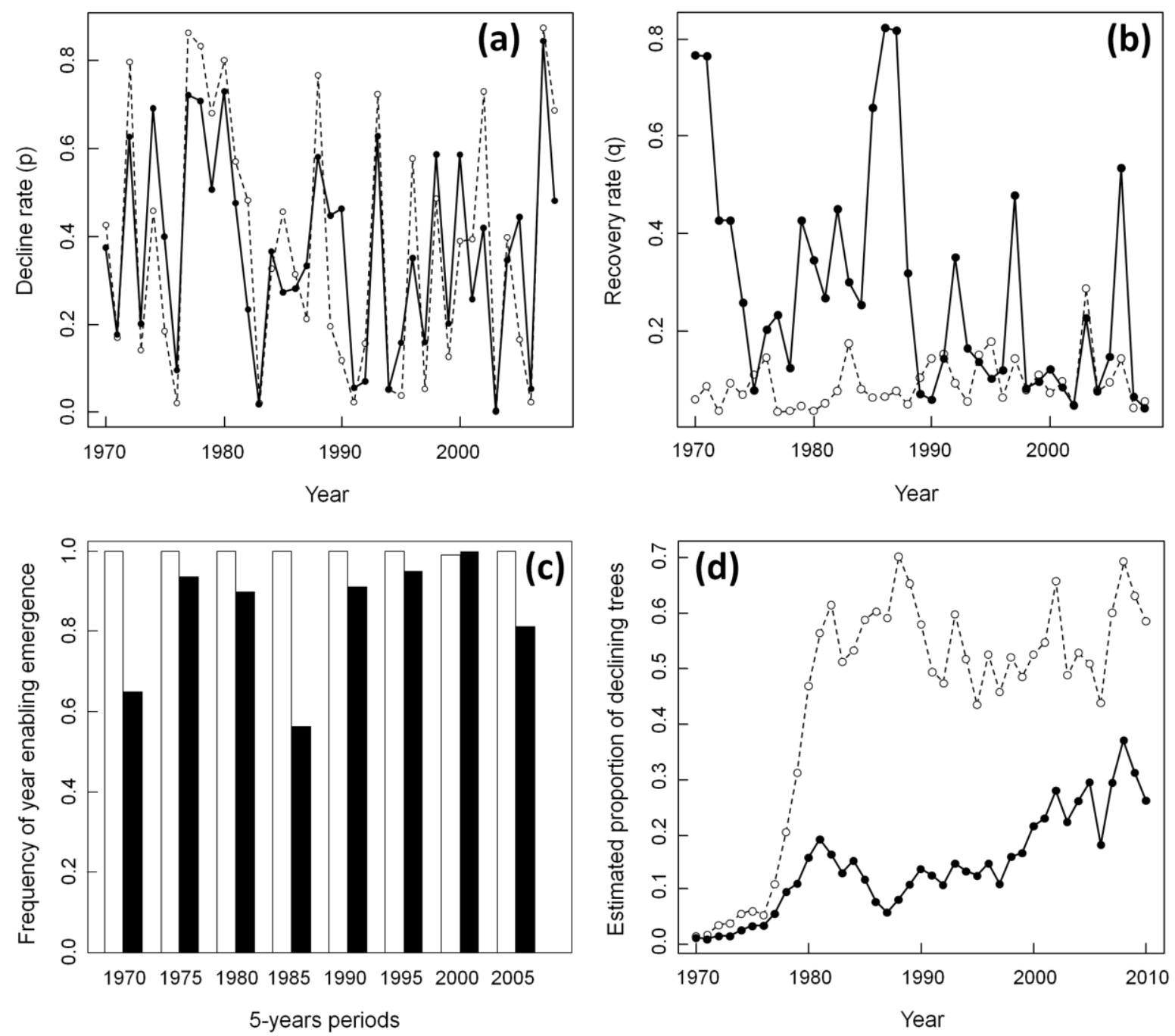

Fig.8. Suitability of past climate for emergence of the $P$. alni induced decline in the monitored sites. Empty symbols and broke, line, Charente area, Filled symbols, RhinMeuse area. a. Annual decline rate $p$. b. Annual recovery rate $q$. c. Frequency of years that enable an increase in the decline prevalence for 5-years period. d. Simulated dynamic of decline prevalence for the 1970-08 period. Each simulation period began with an alder stand with 200 trees among which one was declining, and the change of decline prevalence from winter mean temperatures were simulated according to model presented in figure 2.

\section{Cross-validation of the developed model with data from the Charente area}

Model validity was checked by a cross-validation using the data of the Charente area in SW France. The pattern of decline prevalence over the monitored period was very different in the Charente area compared to the Rhin-Meuse area (Fig. 5). Decline prevalence continuously increased over years in the Charente area with very little evidence of tree recovery. As expected, the climatic conditions were hotter in SW France than in the NE, with mean winter and summer temperature of respectively $7.0 \pm 0.6$ and $20.1 \pm 1.1^{\circ} \mathrm{C}$ for the 1998-03 period (compared to $3.5 \pm 1.1$ and $18.2 \pm 0.7^{\circ} \mathrm{C}$ for the $2006-12$ period in the RhinMeuse area). The correlation between the observed decline prevalence and that predicted by the model was good (Pearson correlation coefficient of 0.792 , Fig. $7 b$ ). A few plots were 
not well represented by the model, with an over-estimation of the disease prevalence. In those plots, observed decline prevalence remained low and very stable over the study period, with no trees transitioning from healthy to declining.

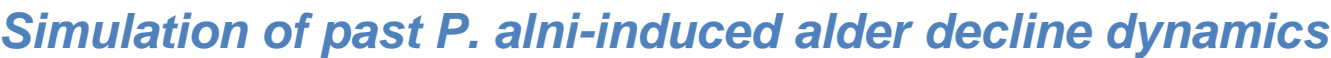

The probability of the development of $P$. alni-induced decline in 38 sites was simulated, based on their observed climatic conditions over a period of 40 years. The simulated decline rate $\left(\mathrm{p}_{\mathrm{t}, \mathrm{j}}\right)$ showed little long term trend from 1970 to 2008 (Fig 8a, $\mathrm{F}=0.97$, pvalue $=0.33$ ). The decline rate $(F=0.02$, pvalue $=0.89)$ and the temporal trend (time * area interaction, $F=0.01$, pvalue $=0.95$ ) were not significantly different between the 2 areas. The difference in recovery rate $\left(\mathrm{q}_{\mathrm{t}, \mathrm{j}}\right)$ between the Rhin-Meuse area and the Charente area was much larger $(F=27.5$, pvalue $<0.001$, see Fig. $8 b)$. Also, the simulated recovery rate showed a significant area-dependent change from 1970 to 2008 (time * area interaction, $F=12.1$, pvalue $<0.001$ ). The recovery rate decreased in the Rhin-Meuse area (Fig. 8b) while it remained stable in the Charente area.

The retrospective use of the built SIS model demonstrated that climatic conditions were suitable for the $P$. alni-induced decline to become established in the 2 major study areas during the majority of the years since 1970. Indeed, climatic conditions enabled the disease to increase from a low initial decline prevalence of $0.5 \%$ in $50-100 \%$ of the years (Fig. $8 \mathrm{c}$ ). However, the conditions for disease establishment improved in the NE of France at the end of the studied period. The comparison of the simulated dynamics of the $P$. alni-induced decline from 1970 to 2008 after an introduction in 1970 showed large differences between the Charente and the Rhin-Meuse areas (Fig. 8d). The climate appeared to be more favorable to the disease in the Charente, in SW France, with an increase in simulated prevalence throughout the period reaching a final decline prevalence of about $60 \%$. By contrast, after an initial increase, the simulated decline prevalence stabilized at around $10 \%$ in NE France, in the Rhin-Meuse area. The simulated decline prevalence was however increased in the last 10 years in the Rhin-Meuse area, and reached about $20-30 \%$, reflecting the decrease in the recovery observed in that area (Fig. 8b and d).

\section{Discussion}

The SIS model we developed during this work explained adequately the dynamics of alder decline in two very different areas of France. $P$. alni-induced alder decline required mild temperatures both for overwintering and during the growing season, with a decreased prevalence of disease after cold winters as well as after hot summers. NE and SW France presented important differences in both the dynamics of crown decline and the climatic constraints on disease development. While overwintering was a limiting factor for disease progress in NE France, it was not in the SW. Thus, tree recovery from decline was frequently observed in NE France, but much less often in the SW.

The data on which the model was built included only the observance of decline in alder; they did not demonstrate that $P$. alni was the cause of each tree's decline. However, $P$. alni has been demonstrated to be the major cause of alder decline in the NE France (Streito \& al, 2002, Thoirain \& al, 2007). Furthermore, we observed the pathogen to be abundant on all the studied sites, being present on most of the baited declining trees. The fact that alder trees can recover from decline is in contradiction with previous views, which considered that infection by $P$. alni always led to tree death (Jung \& Blaschke, 2004; Elegbede et al., 2010), and derives from monitoring of the disease for longer periods (7 years). The main cause of tree recovery could be poor pathogen overwintering in soil. Our study showed a clear annual pattern of $P$. alni viable inoculum at the base of infected trees with limited survival after cold winters. It has already been shown that $P$. alni does not survive severe frost (Schumacher et 
al., 2006; Cerny \& Strnadova, 2012). Indeed, P. alni does not produce chlamydospores, and because it is a triploid homoploid hybrid, it produces non-viable oospores (Delcàn \& Brasier, 2001; Husson, unpublished results). Chlamydospores are mitotic spores produced by many Phytophthora species while oospores are the result of sexual reproduction; both are the thick walled spores that enable Phytophthora to survive harsh conditions (Vercesi et al., 2010; Zhang et al., 2012). As a consequence of this lack of resistant spores, $P$. alni has been demonstrated to persist in soil for only few months in the absence of host (Jung \& Blaschke, 2004; Elegbede et al., 2010), and therefore inoculum levels may be strongly affected by harsh climatic conditions. One possibility is that $P$. alni must induce fine root infections throughout the winter to avoid population crash, and thus needs mild winter temperature to thrive. Another hypothesis is that $P$. alni is eliminated during severe frost. This has been demonstrated for other Phytophthora species such as P. cinnamomi (Marçais et al., 2004), the presence of which is limited in sites where mean winter temperatures are too low (Balci et al., 2007).

Inoculum in the soil showed a strong seasonal pattern, with $P$. alni inoculum levels high in spring after mild winters, but stable in summer and autumn. With warm temperatures and moist soils, spring offers suitable conditions to trigger the development of $P$. alni inoculum that survived the winter. Indeed, Phytophthora species can increase and disseminate their inoculum from low, nearly undetectable levels during a relatively short time of favorable environmental conditions (Jung et al., 2000). An important factor that affects seasonal patterns of soil-borne Phytophthora is moisture (Benson et al., 2006; Shearer et al., 2010, Thompson et al., 2013). However, in our study seasonal dynamics could not be attributed to precipitation, and total rain in the 10-day period preceding sampling was not a relevant variable. This might be explained by the fact that precipitation data were obtained from the nearby meteorological stations, and could have inadequately represented rain patterns on the studied sites. However, it is possible that, as the sites are on river banks, water was not limiting and so precipitation was a less important factor there than in most other Phytophthora diseases.

It is more difficult to interpret the negative correlation between summer temperature and alder decline, with decreasing tree decline incidence and increasing tree recovery rate. $P$. alni has been described as a thermophilous organism with optimal growth temperatures ranges above $22^{\circ} \mathrm{C}$ (Brasier et al., 1995). However, the limiting impact of warm summers occurred at lower temperatures, with a very low optimum for decline induction of about $15^{\circ} \mathrm{C}$. More than a direct effect on the pathogen development, this might reflect changes in microbial communities at that temperature range. Microbial communities are an important factor influencing plant soil borne diseases (Garrett et al., 2011), and seasonal fluctuations of Phytophthora between sites has been demonstrated to reflect changes in levels of the antagonistic microflora population (Shearer \& Shea, 1987; Dirac \& Menge, 2002; Shearer et al., 2010). Sporangia production by $P$. alni is affected by variation in the water microbiota (Chandelier et al., 2006), with microbial communities present in rivers at high temperature decreasing the sporulation. Summer temperature could also influence the decline via an effect on the host tree. For example, Kerns \& Tredway (2008) observed that the optimum for host infection by Pythium volutum was lower than the optimum for growth in vitro, explaining why infection occurs mainly in the autumn and spring when soil temperatures are cooler. Temperature may also have an important effect on zoospore infection (Jeger \& Pautasso, 2008b). Indeed, Shishkoff (2011) showed that inoculum production was higher in roots infected by $P$. ramorum and incubated at $25^{\circ} \mathrm{C}$ than in roots incubated at lower temperatures. It would seem that $P$. alni is not well adapted to high summer temperatures, which might limit the disease in the hottest part of France.

Soil properties, such as the clay / sand or carbon / nitrogen ratios in the soil, appeared to be less important in explaining the $P$. alni soil inoculum levels or the disease severity. However, soil $\mathrm{pH}$, with an optimum of 6.7 , was significant in explaining the quantity of inoculum at the base of the trees. These results are consistent with those of Schumacher et 
al. (2006) and Kong et al. (2012), who estimated that optimal values for $P$. alni sporangia formation are close to neutral $\mathrm{pH}$. The sensitivity to extreme $\mathrm{pH}$ seems to be a shared characteristic with other soil borne Phytophthoras: after a survey in the Bavaria region in Germany, Jung et al. (2000) showed that no species could be isolated from sites where $\mathrm{pH}$ was less than 3.9.

The model we developed proved to be robust as it fitted correctly the dynamic of decline prevalence in sites of SW France that were not used to estimate the parameters. The 2 studied areas presented very different climates in particular for winter conditions. While overwintering was a strong constraint on disease development in NE France, with frequent and significant tree recovery after cold winters, this was not the case in SW France. In this area, as predicted by the model, very little tree recovery occurred. As a result, the model predicted that decline prevalence would reach much higher levels in SW France compared to the NE. The mean prevalence of $55 \%$ observed in 2003 on the Charente plots is representative of the area as plots were selected randomly without taking into account the decline state. By contrast, the 50\% decline prevalence observed in 2007 on the Rhin-Meuse plots is not representative of the area because plots with severe decline were selected to minimize the impact of inoculum availability. Data more comparable to the prevalence of decline observed on the Charente network can be found in Thoirain et al. (2007) where a general survey in the Rhin-Meuse area done in 2004 found a mean decline prevalence of $16 \%$. Thus the P. alni-induced alder decline appears indeed to be far less severe in NE France compared to the SW. Using the SIS model, we showed that the climate in France has been favorable for the establishment of $P$. alni for the 40 last years. There was a trend of decreasing tree recovery rate in the NE and this process could partly explain the emergence of the disease in the 1990's in that area. However, climate has been very favorable to disease emergence in SW France since the early seventies. $P$. alni is the product of an interspecific hybridization event that is supposed to have taken place in nurseries (Jung \& Blaschke, 2004; Schumacher et al., 2006), and one of the parents of the hybrid, P. alni subsp uniformis, has been shown to be exotic in Europe (Aguayo et al., 2013). The emergence of the disease was thus probably the result of planting of contaminated plant material along rivers in a climate that was already suitable, with subsequent spread along the water courses as shown by Jung \& Blaschke (2004).

The model should be extrapolated to different climatic conditions with caution. Indeed, the model test data lacked low summer temperatures, limiting the estimate of the summer temperature optimum for decline rate. For that reason, we did not attempt to predict disease dynamics before 1970. Also, the model we propose does not consider asymptomatic infected trees for P. alni, although Elegbede et al. (2010) showed that these trees were important inoculum producers. Asymptomatic root infections offer a hidden pathway of pathogen transmission and persistence (Fichtner et al., 2010), and not taking this into account certainly leads to an underestimation of the levels of infection and of the pathogen ability to persist. However, within these limits, the model gave interesting insights on possible future dynamic of alder decline. The strong limitation of decline severity imposed in NE France by poor pathogen survival in some winters, as happens in other part of Europe such as eastern Germany or the Czech Republic (Schumacher et al., 2006; Cerny \& Strnadova 2012), clearly questions the future of this disease in a context of climate warming. As winter survival becomes less limiting, disease prevalence could reach levels seen in SW France with severe negative consequences on the ecology of riparian ecosystems. However, warming would not have negative consequences everywhere: in areas of Europe such as SW France, where winter survival does not limit the disease severity, the main consequence of warming could be a strong limitation of the disease during hot summers. In agreement with that hypothesis, the disease is seldom reported by the forest health survey system in the SE part of France, which has hot Mediterranean summers (unpublished results). The disease has also been reported to be mild in Hungary, a country with a continental climate, and warmer summers and colder winters than eastern France (Koltay, 
2007). Thus depending on the present climatic constraints, the impact of a future climate warming on $P$. alni alder decline could lead to very different outcomes.

\section{Acknowledgements}

We wish to thanks the ANR project Emerfundis and the EU project Ecolirimed for financing the project. The UMR1136 is supported by a grant overseen by the French National Research Agency (ANR) as part of the "Investissements d'Avenir" program (ANR11-LABX-0002-01, Lab of Excellence ARBRE). Katherine Hayden has kindly provided comments on the manuscript and language corrections. Olivier Caël, Béranger Bertin, Leslie Becker and Josef Janousek strongly contributed to the project by their technical help. We also thank people of the local technical staff of the Charente area who monitored the plot on this network.

\section{References}

Aguayo J, Adams GC, Halkett F et al. (2013) Strong genetic differentiation between American and European populations of Phytophthora alni subsp. uniformis. Phytopathology, 103, 190-199

Anderson PK, Cunningham AA, Patel NG, Morales FJ, Epstein PR, Daszak P (2004) Emerging infectious diseases of plants: pathogen pollution, climate change and agrotechnology drivers. Trends in Ecology \& Evolution, 19, 535-544.

Balci Y, Balci S, Eggers J, MacDonald WL, Juzwik J, Long RP, Gottschalk KW (2007) Phytophthora spp. Associated with Forest Soils in Eastern and North-Central U.S. Oak Ecosystems. Plant Disease, 91, 705-710.

Bellard C, Thuiller W, Leroy B, Genovesi P, Bakkenes M, Courchamp F (2013) Will climate change promote future invasions? Global Change Biology, 19, 3740-3748.

Benson DM, Grand LF, Vernia CS, Gottwald TR (2006) Temporal and Spatial Epidemiology of Phytophthora Root Rot in Fraser Fir Plantations. Plant Disease, 90, 1171-1180.

Bergot M, Cloppet E, Pérarnaud V, Déqué M, Marçais B, Desprez-Loustau M-L (2004) Simulation of potential range expansion of oak disease caused by Phytophthora cinnamomi under climate change. Global Change Biology, 10, 1539-1552.

Brasier CM, Rose J, Gibbs JN (1995) An unusual Phytophthora associated with widespread alder mortality in Britain. Plant Pathology, 44, 999-1007.

Cerny K, Strnadova V (2012) Winter survival of Phytophthora alni subsp. alni in aerial tissues of black alder. Journal of Forest Science, 58, 328-336.

Chandelier A, Abras S, Laurent F, Debruxelles N, Cavelier M (2006) Effect of temperature and bacteria on sporulation of Phytophthora alni in river water. Communications in agricultural and applied biological sciences, 71, 873-880.

Claessens H (2003) The alder populations of Europe. In: Phytophthora disease of Alder in Europe. (eds Gibbs J, Van Dijk C, and Webber J), Forestry Commission Bulletin 126, Foresty Commission, Edinburgh, p. 82.

Cunniffe NJ, Stutt ROJH, Bosch F van den, Gilligan CA (2011) Time-Dependent Infectivity and Flexible Latent and Infectious Periods in Compartmental Models of Plant Disease. Phytopathology, 102, 365-380.

Delcàn J, Brasier CM (2001) Oospore viability and variation in zoospore and hyphal tip derivatives of the hybrid alder Phytophthoras. Forest Pathology, 31, 65-83

Desprez-Loustau M-L, Robin C, Buée M et al. (2007) The fungal dimension of biological invasions. Trends in Ecology \& Evolution, 22, 472-480.

Dirac MF, Menge JA (2002). High temperatures are not responsible for lack of infection of citrus roots by Phytophthora citrophthora during the summer, but suppressive soil microorganisms may inhibit infection by $P$. citrophthora. Plant and Soil, 241, 243-249. 
Elegbede CF, Pierrat J-C, Aguayo J, Husson C, Halkett F, Marçais B (2010) A statistical model to detect asymptomatic infectious individuals with an application in the Phytophthora alni-induced Alder decline. Phytopathology, 100, 1262-1269.

Fabre B, Piou D, Desprez-Loustau M-L, Marçais B (2011) Can the emergence of pine Diplodia shoot blight in France be explained by changes in pathogen pressure linked to climate change? Global Change Biology, 17, 3218-3227.

Fichtner EJ, Rizzo DM, Kirk SA, Webber JF, (2010) Root Infections May Challenge Management of Invasive Phytophthora spp. in U.K. Woodlands. Plant Disease, 95, 13-18.

Fisher MC, Henk DA, Briggs CJ, Brownstein JS, Madoff LC, McCraw SL, Gurr SJ (2012) Emerging fungal threats to animal, plant and ecosystem health. Nature, 484, 186-194.

Garrett KA, Forbes GA, Savary S et al. (2011) Complexity in climate-change impacts: an analytical framework for effects mediated by plant disease. Plant Pathology, 60, 15-30.

Gilligan CA, Bosch F van den (2008) Epidemiological Models for Invasion and Persistence of Pathogens. Annual Revue Phytopathology, 46, 385-418.

Harvell CD, Mitchell CE, Ward JR, Altizer S, Dobson AP, Ostfeld RS, Samuel MD (2002) Climate warming and disease risks for terrestrial and marine biota. Science, 296, 2158-2162.

loos R, Andrieux A, Marçais B, Frey P (2006) Genetic characterization of the natural hybrid species Phytophthora alni as inferred from nuclear and mitochondrial DNA analyses. Fungal Genetics and Biology, 43, 511-529.

Jeger MJ, Pautasso M (2008a) Plant disease and global change - the importance of long-term data sets. New Phytologist, 177, 8-11.

Jeger MJ, Pautasso M (2008b) Comparative epidemiology of zoosporic plant pathogens. European Journal of Plant Pathology, 122, 111-126.

Jung T, Blaschke M (2004) Phytophthora root and collar rot of alders in Bavaria: distribution, modes of spread and possible management strategies. Plant Pathology, 53, 197-208.

Jung T, Blaschke H, Oßwald W (2000) Involvement of soilborne Phytophthora species in Central European oak decline and the effect of site factors on the disease. Plant Pathology, 49, 706718.

Kerns JP, Tredway LP (2008) Influence of Temperature on Pathogenicity of Pythium volutum Toward Creeping Bentgrass. Plant Disease, 92, 1669-1673.

Koltay A (2007) New results of the research on the Alder Phytophthora disease in Hungarian Alder stands. (ed Szabo I). Acta Silvatica \& Lignaria Hungarica, Special, 209-213

Kong P, Lea-Cox JD, Moorman GW, Hong C (2012) Survival of Phytophthora alni, Phytophthora kernoviae, and Phytophthora ramorum in a simulated aquatic environment at different levels of $\mathrm{pH}$. FEMS Microbiology Letters, 332, 54-60.

Kupferschmidt K (2012) Attack of the Clones. Science, 337, 636 -638.

.Marçais B, Bergot M, Pérarnaud V, Levy A, Desprez-Loustau M-L (2004) Prediction and Mapping of the Impact of Winter Temperature on the Development of Phytophthora cinnamomi-Induced Cankers on Red and Pedunculate Oak in France. Phytopathology, 94, 826-831.

Mundt C, Sackett K, Wallace L, Cowger C, Dudley J (2009) Aerial Dispersal and Multiple-Scale Spread of Epidemic Disease. EcoHealth, 6, 546-552.

Neri FM, Bates A, Füchtbauer WS, et al. (2011) The Effect of Heterogeneity on Invasion in Spatial Epidemics: From Theory to Experimental Evidence in a Model System. PLoS Computational Biology 7, e1002174.

Pritchard SG (2011) Soil organisms and global climate change. Plant Pathology, 60, 82-99.

Quintana-Seguí $P$, Le Moigne P, Durand $Y$ et al. (2008) Analysis of near surface atmospheric variables: Validation of the SAFRAN analysis over France. Journal of Applied Meteorology and Climatology, 47, 92-107

Schumacher J, Leonhard S, Grundmann BM, Roloff A (2006) New Alder disease in Spreewald biosphere reserve - causes and incidental factors of an epidemic. Nachrichtenblatt des Deutschen Pflanzenschutzdienstes, 58, 141-147.

Shaw MW, Bearchell SJ, Fitt BDL, Fraaije BA (2008) Long-term relationships between environment and abundance in wheat of Phaeosphaeria nodorum and Mycosphaerella graminicola. New Phytologist, 177, 229-238. 
Shearer B, Dillon M, Kinal J, Buehrig R (2010) Temporal and spatial soil inoculum dynamics following Phytophthora cinnamomi invasion of Banksia woodland and Eucalyptus marginata forest biomes of south-western Australia. Australasian Plant Pathology, 39, 293-311.

Shearer BL, Shea SR (1987) Variation in seasonal population fluctuations of Phytophthora cinnamomi within and between infected Eucalyptus marginata sites of southwestern Australia. Forest Ecology and Management, 21, 209-230.

Shishkoff N (2011) A Test System to Quantify Inoculum in Runoff from Phytophthora ramorumInfected Plant Roots. Phytopathology, 101, 1457-1464.

Stenlid J, Oliva J, Boberg JB, Hopkins AJM (2011) Emerging Diseases in European Forest Ecosystems and Responses in Society. Forests, 2, 486-504.

Streito JC, Legrand P, Tabary F, Villartay GJD (2002) Phytophthora disease of alder (Alnus glutinosa) in France: investigations between 1995 and 1999. Forest Pathology, 32,179-191.

Thoirain B, Husson C, Marçais B (2007) Risk factors for the Phytophthora-induced decline of Alder in Northeastern France. Phytopathology, 97, 99-105.

Thompson SE, Levin S, Rodriguez-Iturbe I (2013) Linking plant disease risk and precipitation drivers: A dynamical systems framework. The American Naturalist, 18, E1-E16

Vercesi A, Toffolatti S, Zocchi G, Guglielmann R, Ironi L (2010) A new approach to modelling the dynamics of oospore germination in Plasmopara viticola. European Journal of Plant Pathology, 128, 113-126.

Zhang Y, Pu Z, Qin Z, Zhou X, Liu D, Dai L, Wang W (2012) A Study on the Overwintering of Cucumber Downy Mildew Oospores in China. Journal of Phytopathology, 160, 469-474. 